Service for his co-operation in supplying ammocœtes of $P$. marinus.

M. W. Hardisty

Department of Chemistry and Biology, College of Technology, Bristol.

1 Hardisty, M. W., Nature, 173, 874 (1954).

2 Young, R. T., and Cole, L. J., Amer. Nat., 34, 617 (1900).

3 Reighard, J., Science, 17, 529 (1903).

4 Okkelberg, P., J. Morph., 35 (1926).

${ }^{\circ}$ Schultze, L. P., Occ. Pap. Mus. Zool. Univ. Mich., 221, 1 (1930).

- Ivanova-Berg, M. M., Zool. Anz., 96, 330 (1931).

"Zanandirea, G., Boll. Pese. Pisc, e Idrobiol., 8, 1 (1951).

${ }^{8}$ A pplegatc, V. C., U.S. Fish and Wildl. Serv. Spec. Rep., 55, 1 (1950).

\section{Caretta kempi Garman on Welsh Coast}

ON January 3, a Mexican or Kemp's loggerhead turtle, Caretta kempi Garman, was found at highwater mark on Kenfig Dunes in Glamorgan. It was dead, but the body was in a good state of preservation, though the shields of the carapace were mostly missing. The weight was $2,420 \mathrm{gm}$., the carapace being $244 \mathrm{~mm}$. long and $224 \mathrm{~mm}$. at its maximum width; the length of the plastron was $199 \mathrm{~mm}$. Two other specimens of this species, one slightly larger and one slightly smaller, are in the collection of this Department, both taken alive; one near Freshwater West on the Pembrokeshire coast, in December 1930, the other at Mochras Island at the north end of Cardigan Bay, in November of the same year.

In December 1938, an example of the other species of loggerhead recorded from Britain, Caretta caretta (Linn.), was stranded near Tenby ; while in February 1946 one weighing $8,180 \mathrm{gm}$. was found alive on the beach at Oxwich, Glamorgan, and is now in our collections.

Whereas Caretta caretta appears to have a fairly wide distribution in tropical and sub-tropical waters on both sides of the Atlantic (though the breeding grounds are on the American side), the natural habitat of the smaller Caretta kempi is stated to be re. stricted to the Gulf of Mexico and adjacent waters, and it is less likely to be carried to the British coasts. About twenty British occurrences of the former, as compared with ten of the latter species, have been recorded ${ }^{1}$.

Deraniyagala $^{2}$ suggested that the presence of loggerheads in European waters was probably due mainly or entirely to currents, and that they might be of importance as current-indicators; and Parker ${ }^{3}$, discussing turtle strandings in 1938 on British coasts, considered it "difficult not to associate their coming with the remarkably warm weather and almost uninterrupted series of south-westerly gales which characterized late November and early December. It seems probable that there has been a strong indrift of warm surface water into the English Channel from the south-west". Russell ${ }^{4}$ suggested another possible explanation-the general extension in recent times of warm water farther towards the Arctic, with a resultant northward extension of the boundaries of certain animals. $\mathrm{He}$ instanced the capture of a flying fish, Cypsilurus heterurus, in Oslo harbour in 1937; and it may be noted also that a Caretta caretia was found stranded on the Norwegian coast in December $1951^{5}$. No loggerhead had ever before been recorded from Scandinavian waters nor from the area east and north of Shetland.

From information supplied by Mr. H. H. Lamb of the Meteorological Office, it would not appear that the warm summer of 1959 over Britain and Europe had any connexion with the present occurrence of
C. kempi on the Welsh coast. In fact the western two-thirds of the North Atlantic were colder in 1959 than for many years past, only the Bay of Biscay, the North Sea and waters east of about $20^{\circ} \mathrm{W}$. being slightly warmer than average. It seems much more likely to be associated with some anomaly of the prevailing water currents. Over the north-eastern Atlantic, especially the waters around the British. Isles and farther north, there was a remarkable prevalence of southerly winds in the autumn of 1959 . The autumn and early winter, including December, were also notable for the repeated occurrence of a great sweep of west to north-west winds across the whole width of the Atlantic fanning cold water eastwards towards the Bay of Biscay; and this might possibly have produced a flow of water from the Bay of Biscay northwards to the shores of Britain.

Note added in proof. Since the above was written, I have been informed that the British Museum (Natural History) received a specimen of Caretta caretta found alive at South Uist on January 8 this year.

Department of Zoology, Colin Matheson

National Museum of Wales, Cardiff.

${ }^{1}$ Smith, M., "The British Amphibians and Reptiles", 264 (1954). 2 Deraniyagala, P. E. P., Nature, 142, 540 (1938).

${ }^{2}$ Parker, H. W., Nature, 143, 121 (1939).

“ Russell, F. S., Nature, 143, 206 (1939).

3 Willgohs, J. F., Universitetet i Bergen Arbok 1952, Naturvitenskapelig rekke, No. 17,3 (1953).

\section{Elminius modestus Darwin in South-West Scotland}

THE present status of Elminius modestus Darwin in the British Isles has recently been summarized by Crisp and Southward". Thoy state that in 1958-59 "it is still relatively rare in Luce Bay and has not yet passed the Mull of Galloway. Similarly, there has been little change in the isolated and sparse colony in Lough [Loch] Ryan at the entrance to the Clyde Sea". In an earlier publication, Crisp ${ }^{2}$ states that this Stranraer population, although dwindling in numbers, has persisted since 1950 and consists largely of old animals with corroded shells. According to his classification of abundance, rare is taken as "less than $1 / \mathrm{m}^{2}$; only a few isolated specimens in 1 hour's search" and occasional as " $1-100 / \mathrm{m}^{2}$; often local and need ing to be searched for ; rarely close enough to breed".

Over a number of years we have been making an annual survey of the density of settlement of barnacles in the Clyde sea area and our observations on the present status of Elminius modestus in south-west Scotland are not entirely in agreement with those quoted above. The following results refer to early August 1959.

Elminius modestus is unevenly distributed in Luce Bay, possibly because of variations in local hydrographical conditions caused by a curious development of shingle spits. Nevertheless, it is readily found in many places, being most common on the western shore; for example, on an artificial structure running across the beach near Sandhead adults at a density of $1 / \mathrm{cm} .^{2}$, young at $8-10 / \mathrm{cm} .^{2}$ and spat at $5-10 / \mathrm{cm}^{2}$ were recorded. On parts of the shore at Drummore the species is common with individuals up to $2 / \mathrm{cm}^{2}$. Furthermore, the species has passed the Mull of Galloway since it was found at Port Logan on the open coast; although not common here, small groups were near enough for breeding if they roached maturity; large adults were not found. 